\title{
БЕЗЭТАЛОННОЕ ИЗМЕРЕНИЕ КАК МЕТОД ИССЛЕДОВАНИЯ НРАВСТВЕННОСТИ
}

\section{О.П. Пунченко}

Спектр методологических проблем современного социального познания довольно широк, но это не означает, что в методологии научного поиска наука достигла абсолюта, а тем более в анализе социального бытия человечества. В частности, основными методами исследования нравственности являются метод конкретно-исторического подхода, метод восхождения от абстрактного к конкретному, метод анализа, а также социального прогнозирования. «Өффективность каждого метода научного познания обусловлена содержательностью, глубиной и фундаментальностью теории, - отмечает В.П. Кохановский, - которая „сжимается в метод“. В свою очередь, „метод расширяется в систему", т. е. используется для дальнейшего углубления и развертывания знания, его материализации в практике» [3, с. 250].

Эта же идея нашла свое отражение и у В.К. Лукашевича, который утверждает, что «в идеале метод стремится» быть обоснованным теорией. Привлекательность этого варианта не только в том, что теория наиболее системная и информационно емкая форма истинного предметного знания, но и в том, что она включает аппарат, регламентирующий развертывание ее собственного содержания без обращения к дополнительным источникам информации. А отсюда легко сделать следующий шаг и прийти к выводу, что «метод есть теория, обращенная на получение нового знания» $[4$, с. 6]. Следовательно, в структуре метода главным является интенция на отражение системного качества исследуемого явления или процесса.

На основе такого понимания содержания научного метода появляется реальная возможность расширения методологической базы иссле- 
дования нравственности. Во-первых, с позиций широкого применения конструктивной философской критики как рациональной формы познания социальных явлений. Нравственность - это тот объект социального познания, где шире всего применяется рационализм, а философская критика есть не что иное, как движение мысли субъекта о реалиях бытия. Она есть форма движения знания, слагаемое познания, его элемент, она способствует выявлению противоречий в объекте, выступающем в качестве его критического философского анализа. Подход к анализу нравственности с позиций философской критики обеспечивает обоснование се конструктивного характера, способности реализации инфраструктуры нравственности как совокупности условий и предпосылок, обеспечивающих единство ее теории и практики.

Во-вторых, есть необходимость проанализировать содержание нравственности с позиций системно-структурного анализа, а точнее, с позиций общей параметрической теории систем, провести системно-дескрипторный анализ нравственности, ее инноваций как ценностно-духовной синергии общества, при этом обосновать ее концепт, структуру и субстрат.

И, в-третьих, а это для нашей статьи главное, необходимо обосновать сущность метода безэталонного измерения и применить его к исследованию нравственности как открытой незаангажированной системе. Эта потребность объясняется тем, что в методологии познания социальных явлений, и в частности в нравственности, возникает настоятельная необходимость выделения объективных критериев, отражающих содержание, качество и эффективность понятий и категорий нравственности. Эти критерии требуют анализа с позиций возможности их измерения. Но здесь сразу же возникают трудности, связанные с тем, что в измерении социальных процессов преобладает субъективное начало. И в какой-то мере можно согласиться с В.В. Готынян, что поскольку «четкого алгоритма безэталонного измерения нет до сих пор и мы, руководствуясь одними только нам известными критериями и по одному только нам известному механизму, „измеряем“ красоту, глупость, честность... Мы так привыкли безэталонно измерять, не отдавая себ́е отчета в том, что произвели измерение, что только необходимость поиска новых путей измерений. . . заставила нас вспомнить о безэталонном измерении» $[2$, с. 39$]$.

В естественных и технических науках метод измерения получил свою классическую трактовку прежде всего как измерение эталонное. Обычно такое измерение применяется к предметам, где субъект познания стремится сравнить его с эталоном. Эталонное измерение хара- 
ктерно для естественных и технических наук. Это такие виды измерения как механические, электрические, радиотехнические, теплотехнические и другие, где можно широко использовать приборы, способные сопоставить исследуемый предмет с эталоном. Человечество не зря пополняет Палату мер и весов - это уникальное хранилище эталонов для всех народов.

Эталонное измерение является ведущим доминирующим видом измерения в современной науке, но оно основывается еще на представлениях пифагорийской школы. Благодаря идеям, разработанным представителями этой школы, число становится неотъемлемой частью измерения, постепенно оно начинает «овладевать миром», выступая как единственно возможный результат измерения. Это явление названо «пифагорийским синдромом в науке» и сегодня нашло широкое исследование и использование в практике количественного анализа.

Однако, кроме количественного анализа существует качественный анализ, который также был исследован еще в философии Древней Греции и известный как квалитативизм Аристотеля. Использование квалитативизма связано с рядом трудностей, которые заключаются в отсутствии четкой методологии качественного анализа. В более поздних философских системах проблема безэталонного измерения применялась прежде всего к объяснению материальных объектов, а что касается понятий и категорий социальной философии, то метод измерения в его безэталонном формате не подвергался глубокому исследованию. Почему же сложилась такая ситуация? Дело в том, что существует много понятий и категорий в социальной философии, которые по своей природе не могут иметь эталона. Особенно это проявляется в нравственности. «Переоценка ценностей», норм, поведения, этика взаимных отношений требует необходимости определить, а точнее, измерить не только уровень осведомленности личности, но и такие ее качества как честность, порядочность, совесть, т.е. те качества, которье нельзя измерить с помощью эталона. Собственно для решения этих проблем возникает потребность в новой методологии измерения безэталонной.

Метод безэталонного измерения в исследовании нравственности выступает как синтез ее предметного и инструментального содержания. Обоснование предметным знанием совокупности принципов, норм, правил, предписаний, составляющих операциональное содержание метода безэталонного измерения влечет за собой очень важное эвристическое следствие - формирование новых предметных представлений о содержании понятий и категорий нравственной реальности. 
Эти представления превращаются в истинное предметное знание по мере успешного обоснования посредством метода безэталонного измерения, актуальных для нравственности проблем. Доказывая таким образом свою истинность, данный метод обеспечивает прирашение предметного знания не только за счет следования его предписаниям, но и непосредственно через свое концептуальное содержание.

Но если речь идет о безэталонном измерении, то встает вопрос о возможности экспликации этой категории. В этом плане безэталонное измерение можно рассматривать как общепризнанный человечеством интервал, в рамках которого позитивно функционирует содержание данного нравственного понятия или категории. Нравственные категории, и структурные, такие как норма, принцип, оценка, идеал, взгляды, знания, убеждения, чувства, привычки, обычаи, поступки, и сущностные, такие как - добро и зло, совесть и стыд, доброжелательность и порок, долг, достоннство и честь, счастье и другие, - не могут иметь единого количественного эталона, поскольку они функционируют как мера духовного бытия личности и не могут быть измерены как раз и навсегда данное, устоявшееся. Несомненно, в своем содержании они не догмы, а развивающиеся в отношениях человека и общества системы. И можно говорить о долге, совести, справедливости, но измерить их единым эталоном нельзя. Они функционируют в интервале требований, удовлетворяющих общество, но выражение их содержания отражает ту самость человека, которую никогда человечество не сможет эталонизировать, как нечто общее для всех. Уникальность духовного мира каждой личности можно охарактеризовать только с позиций безэталонного измерения. И проводить методологический анализ нравственности необходимо с учетом этого метода познания - безэталонного измерения.

Анализ безэталонного измерения позволяет утверждать о возможности выделения в его содержании различных видов. Это связано с тем, что как метод социального познания безэталонное измерение можно рассматривать как полный анализ качественного описания исследуемого (в нашем случае нравственного) явления, т. е. будет иметь в этом случае место экспликация свойств этого явления без отражения результата в количественной форме, без использования эталона и без фиксирования единиц измерения.

Например, один из видов безэталонного измерения, который используется в социальном познании, основан на сопоставлении, когда в анализе нравственной практики личности мы сопоставляем его поступки, принципы, убеждения, выполнение ею долга, с требования- 
ми, предъявляемьми социумом к нравственному поведению человека. Этому виду безэталонного измерения свойственна операция сравнения, в ходе которой вырабатывается моральная оценка поведения и действий личности. Но и в этом случае нет четко фиксированного эталона, утвержденного международными стандартами образца. Его функции в процессе безэталонного измерения выполняет признак квазиэталон, с которым сравнивается нравственное действие. Однако здесь прослеживается большая зависимость в оценке нравственного действия от квазиэталона. Поскольку квазиэталон выступает в качестве заместителя эталона, то ему присуще субъективное начало, которое отражается на оценке рассматриваемого нравственного действия.

В то же время использование квазиэталона в системе научного знания содержит в себе ту опасность, когда не разграничивают эталонное и безэталонное измерение. Например, в физике микромира безэталонное измерение может быть применено как момент сравнения и результат этого сравнения выражают числом, что стирает грань между видами измерений. В ряде случаев исследователи считают, что не существует абсолютного размежевания между эталонными и безәталонными измерениями, так как безэталонное измерение как бы трансформируется в эталонное, подобно тому как в логике «дихотомический раздел аналогичен членению объекта на две части» $[1$, с. 77]. Но в данном случае не учитывается специфика безэталонного измерения в общественных отношениях.

\section{1 Литература}

[1] Готиняи B.B. Про одну логічну відмінність еталонного та безеталонного вимірювань // Перспективи. - 2002. - №2(18) - C. $71-$ 78.

[2] Готынян B.B. К вопросу о соотношении эталонного и безэталонного измерений // Перспективи. - 2002. - № 3(19). - С. 34-40.

[3] Кохановский В.П. Философские проблемы социально-гуманитарных наук. - Р/Д.: Феникс, 2005.

[4] Лукашевич B.К. Научный метод: структура, обоснование, развитие.- Минск: Наука і тэхніка, 1991. 